Article

\title{
Agro-Morphological Characterization and Some Seed Characteristics of Wild Crambe (Brassicaceae) Species in Turkey
}

\author{
Ilhan Subaşı 1 D \\ Department of Seed Science and Technology, Faculty of Agriculture, Bolu Abant İzzet Baysal University, \\ Bolu 14030, Turkey; ilhan.subasi@ibu.edu.tr; Tel.:+90-3742534345
}

check for updates

Citation: Subaşı, I.

Agro-Morphological Characterization and Some Seed Characteristics of Wild Crambe (Brassicaceae) Species in Turkey. Sustainability 2022, 14, 287. https://doi.org/10.3390/su14010287

Academic Editor: Sezai Ercisli

Received: 23 November 2021 Accepted: 14 December 2021 Published: 28 December 2021

Publisher's Note: MDPI stays neutral with regard to jurisdictional claims in published maps and institutional affiliations.

Copyright: (C) 2021 by the author. Licensee MDPI, Basel, Switzerland. This article is an open access article distributed under the terms and conditions of the Creative Commons Attribution (CC BY) license (https:// creativecommons.org/licenses/by/ $4.0 /)$.

\begin{abstract}
The seeds of wild Crambe species have potential to be used as a source of industrial oil and animal feed. In this study, 48 genotypes of three Crambe species collected from the flora of Turkey were grown under field conditions in Ankara/Turkey in 2014-2016. The seed protein ratio, plant height, number of branches per plant, number of seeds per plant, seed yield per plant, thousand seed weight and hulless/hulled seed ratio $(\mathrm{H} / \mathrm{H})$ were determined. The highest protein ratio was determined as $26.02 \%$ in the 18 accession of Crambe tataria species. Variations in the characteristics were analyzed using principal component analysis. In the factor analysis of Crambe maritima, Crambe orientalis, Crambe tataria and the mean of these three species, the first two principal components accounted for $100 \%, 58.06 \%, 59.93 \%$ and $100 \%$ of the total variations, respectively. There were positive correlations between the plant height and number of seeds per plant, seed yield per plant for C. orientalis, and number of branches per plant for C. tataria. Although seed yield per plant was high in C. tataria and C. orientalis, they are not suitable for conventional agriculture due to shell thickness, inhomogeneous plant emergence and shooting. Conventional cultivation of wild Crambe species can be made possible by eliminating these negative features with breeding and agronomic studies.
\end{abstract}

Keywords: wild Crambe; agro-morphology; protein ratio; crop wild relatives; genetic resources

\section{Introduction}

The genus Crambe, which is a member of the family Brassica, comprising 338 genera and 3709 species, has approximately 35 taxa worldwide [1]. The flora of Turkey includes six species and four infraspecific taxa [2], comprising Crambe alutacea Hand.-Mazz., C. tataria Sebeök var. tataria, C. grandiflora DC., C. hispanica L., C. maritima L., C. orientalis L. subsp. orientalis var. dasycarpa O. E. Schulz, C. tataria Sebeök var. parviflora Hedge and Hub.-Mor., C. orientalis L. subsp. orientalis var. orientalis, C. orientalis L. subsp. sulphurea Prina, and C. tataria Sebeök var. aspera Boiss [3,4].

Like many members of the family Brassica, the genus Crambe is a new potential plant that could be a source of industrial oil [1]. The majority of Crambe species can easily be cultivated to provide high crop yields. They can also be used as melliferous, starch-bearing green fodder, or as decorative plants [5]. The oil obtained from Crambe abysinica has high erucic acid content and has been used as an antiadhesion in the nylon and plastics industries. Crambe abyssinica Hochst, an annual Crambe species, has widespread industrial use and has been widely studied. As with many other wild Crambe species, those investigated herein were perennial.

Wild relatives have the potential to improve the beneficial characteristics of the crop, such as its resistance to biotic and abiotic stresses, enriching the gene pool and enhancing the yield, maturity period and quality [6]. Many agronomic characteristics, such as cytoplasmic and nuclear male sterility, resistance to disease, insects and nematode pests, intermediate C3-C4 photosynthetic activity, and tolerance to cold, salt and drought conditions, have been transferred from wild plant species to cultivated plants [1]. Morphological characterization is the first stage in the definition and classification of genetic resources [7]. 
The collection and characterization of a wide range of genetically diverse crops are essential for beginning a successful breeding program [7-9].

It is important to determine the agromorphological characteristics and some seed characteristics in order to determine the potential of wild Crambe species to be cultivated, and brought into the economy. The aim of this study is to determine the yield and some agromorphological characteristics of wild Crambe species in Turkey, under conventional farming conditions.

\section{Materials and Methods}

\subsection{Plant Material and Crop Sowing}

The plant material consisted of 48 accessions belonging species of $C$. orientalis, C. tataria, and C. maritima. The species of Crambe used in the field experiment were previously collected in Turkey. This is the most comprehensive study ever made, covering all species of Crambe and their accessions in Turkey. In this study, 3 accessions for C. maritima, 22 accessions for $C$. orientalis, and 23 accessions for $C$. tataria were used. The localities and altitudes of the studied wild Crambe accessions are given in Table 1.

Table 1. List of investigated Crambe germplasm accessions and localities.

\begin{tabular}{|c|c|c|c|c|c|}
\hline Code & Species & Origin & Code & Species & Origin \\
\hline & $\begin{array}{l}\text { Crambe maritima } \\
\qquad(2 \mathrm{n}=30 ; 60)\end{array}$ & & & $\begin{array}{c}\text { Crambe tataria } \\
(2 \mathrm{n}=30 ; 60 ; 120)\end{array}$ & \\
\hline $\mathrm{m} 1$ & C. maritima & Sinop & $\mathrm{t} 1$ & C. tataria var. aspera & Aksaray \\
\hline $\mathrm{m} 2$ & C. maritima & Kastamonu & $\mathrm{t} 2$ & C. tataria var. tataria & Aksaray \\
\hline \multirow[t]{3}{*}{$\mathrm{m} 3$} & C. maritima & Kastamonu & $\mathrm{t} 3$ & C. tataria var. tataria & Aksaray \\
\hline & & & $\mathrm{t} 4$ & C. tataria var. tataria & Kırşehir \\
\hline & Crambe orientalis $(2 n=30)$ & & $\mathrm{t} 5$ & C. tataria var. tataria & Afyon \\
\hline o1 & C. orientalis var. orientalis & Kayseri & t6 & C. tataria var. tataria & Kırşehir \\
\hline $\mathrm{o} 2$ & C. orientalis var. orientalis & Nevşehir & $\mathrm{t} 7$ & C. tataria var. tataria & Kirikkale \\
\hline o3 & C. orientalis var. orientalis & Kahramanmaraş & $\mathrm{t} 8$ & C. tataria var. tataria & Ankara \\
\hline o4 & C. orientalis var. orientalis & Aksaray & t9 & C. tataria var. tataria & Bilecik \\
\hline o5 & C. orientalis var. orientalis & Kahramanmaraş & $\mathrm{t} 10$ & C. tataria var. aspera & Eskişehir \\
\hline o6 & C. orientalis var. orientalis & Sivas & $\mathrm{t} 11$ & C. tataria var. tataria & Ankara \\
\hline o7 & C. orientalis var. orientalis & Nevşehir & $\mathrm{t} 12$ & C. tataria var. tataria & Kırıkkale \\
\hline o8 & C. orientalis var. orientalis & Kayseri & $\mathrm{t} 13$ & C. tataria var. tataria & Eskişehir \\
\hline o9 & C. orientalis var. orientalis & Nevşehir & $\mathrm{t} 14$ & C. tataria var. tataria & Eskişehir \\
\hline o10 & C. orientalis var. orientalis & Afyon & $\mathrm{t} 15$ & C. tataria var. aspera & Ankara \\
\hline o11 & C. orientalis var. orientalis & Çankırı & $\mathrm{t} 16$ & C. tataria var. tataria & Eskişehir \\
\hline o12 & C. orientalis var. orientalis & Ankara & $\mathrm{t} 17$ & C. tataria var. tataria & Kirıkkale \\
\hline o13 & C. orientalis var. orientalis & Ankara & $\mathrm{t} 18$ & C. tataria var. tataria & Ankara \\
\hline o14 & C. orientalis var. orientalis & Adıyaman & $\mathrm{t} 19$ & C. tataria var. tataria & Sivas \\
\hline o15 & C. orientalis var. orientalis & Malatya & $\mathrm{t} 20$ & C. tataria var. tataria & Ankara \\
\hline o16 & C. orientalis var. sulphurea & Kahramanmaraş & $\mathrm{t} 21$ & C. tataria var. tataria & Eskişehir \\
\hline o17 & C. orientalis var. orientalis & Kahramanmaraş & $\mathrm{t} 22$ & C. tataria var. tataria & Kayseri \\
\hline o18 & C. orientalis var. sulphurea & Kahramanmaraş & $\mathrm{t} 23$ & C. tataria var. aspera & Ankara \\
\hline o19 & C. orientalis var. orientalis & Kayseri & & & \\
\hline $\mathrm{o} 20$ & C. orientalis var. dasycarpa & Adana & & & \\
\hline $\mathrm{o} 21$ & C. orientalis var. orientalis & Kahramanmaraş & & & \\
\hline $\mathrm{o} 22$ & C. orientalis var. orientalis & Kayseri & & & \\
\hline
\end{tabular}

Field experiments were conducted during the 2014-2016 crop season at the research and implementation area of the Central Research Institute for Field Crops, in Ankara, Turkey ( $\left.39^{\circ} 95^{\prime} 59^{\prime \prime} \mathrm{N} ; 32^{\circ} 81^{\prime} 49^{\prime \prime} \mathrm{E}\right)$.

Within the scope of the field studies, seeds collected from the localities were sowed in October of 2014 at a plant density of $70 \mathrm{~cm} \times 30 \mathrm{~cm}$ and $5 \mathrm{~m}$ row length. The emergence of the plants was observed in the spring of 2015. Since the Crambe species studied are perennial, no flowering was observed in 2015. All observations within the scope of the study were recorded in the summer of 2016. Each parameter was determined as the mean 
of 10 plant measurements in each row. For each accession, morphological and agronomical properties were recorded, comprising the seed protein ratio (PR), plant height (PH), seeds per plant (SPP), yield per plant (YPP), thousand seed weight (TSW), hulless/hulled seed ratio $(\mathrm{H} / \mathrm{H})$, and number of branches per plant $(\mathrm{BPP})$. Data were measured and recorded according to International Plant Genetic Resources Institute procedures. The average height of 10 plants, measured from ground level to the top of the plant, was recorded as the $\mathrm{PH}$. The BPP was calculated with the mean values of the number of branches of 10 plants. The TSW was obtained by weighing 4 replicates of 100 seeds. The SPP was calculated as the average of the number of seeds of 10 plants taken from each row.

\subsection{Climate and Soil Properties of the Test Field}

Total precipitation was $490 \mathrm{~mm}$ during 2014, $467 \mathrm{~mm}$ in 2015, and $388 \mathrm{~mm}$ in 2016. The lowest and highest temperatures were recorded in 2014 as $-8.8^{\circ} \mathrm{C}$ in February and $37.8^{\circ} \mathrm{C}$ in August; in 2015 as $-15.5^{\circ} \mathrm{C}$ in January and $37.7^{\circ} \mathrm{C}$ in July; and in 2016 as $-16.4^{\circ} \mathrm{C}$ in January and $38.2{ }^{\circ} \mathrm{C}$ in July. The test field in which the research was conducted consisted of well-drained, loamy-clayey soil. The soil $\mathrm{pH}$ was 7.97 , the percentage of salt was $0.015 \%$, organic matter was $1.36 \%$, and lime was $7.02 \%$. The altitude of the trial area was $846 \mathrm{~m}$.

Statistical analyses: Statistical analyses were performed with JMP Pro 11 (SAS Institute, Cary, NC, USA). Correlation among the properties was calculated using the Pearson correlation procedure. Trait mean values were used to perform principal component analysis (PCA).

\section{Results}

Among the Crambe species, the average $\mathrm{PH}$ was highest in C. orientalis $(132.33 \mathrm{~cm})$ and lowest in C. maritima $(79.05 \mathrm{~cm})$. The average BPP was highest in C. orientalis (14.57 branches) and lowest in C. maritima (9.17 branches). The average SPP was highest in C. tataria (12,806.34 seeds) and lowest in C. maritima (1397.87 seeds). The average yield per plant was the highest in C. tataria $(215.00 \mathrm{~g})$ and lowest in C. maritima $(75.75 \mathrm{~g})$. The average TSW was the highest in C. maritima $(58.53 \mathrm{~g}$ ) and the lowest in C. orientalis $(10.05 \mathrm{~g})$. The average $\mathrm{H} /$ Hwas highest in C. orientalis $(54.73 \%)$ and lowest in C. maritima $(31.00 \%)$. The average PR was highest in C. orientalis (22.66\%) and lowest in C. maritima (16.84\%) (Table 2).

Table 2. Average values of the seed protein ratio and plant characteristics of Crambe species grown under field conditions.

\begin{tabular}{|c|c|c|c|c|c|c|c|c|}
\hline \multicolumn{2}{|c|}{ Species } & \multirow{2}{*}{$\begin{array}{c}\begin{array}{c}\text { Plant } \\
\text { Height } \\
\text { (cm) }\end{array} \\
75.00\end{array}$} & \multirow{2}{*}{$\begin{array}{c}\text { Branches } \\
\text { per Plant } \\
\text { (number) }\end{array}$} & \multirow{2}{*}{$\begin{array}{c}\begin{array}{c}\text { Seeds per } \\
\text { Plant } \\
\text { (number) }\end{array} \\
581.18\end{array}$} & \multirow{2}{*}{$\begin{array}{c}\text { Yield per } \\
\text { Plant (g) } \\
38.82\end{array}$} & \multirow{2}{*}{$\begin{array}{c}\begin{array}{c}\text { Thousand } \\
\text { Seed } \\
\text { Weight (g) }\end{array} \\
48.35\end{array}$} & \multirow{2}{*}{$\begin{array}{c}\text { Hulless/ } \\
\text { Hulled Seed } \\
\text { Ratio (\%) }\end{array}$} & \multirow{2}{*}{$\begin{array}{c}\begin{array}{c}\text { Seed } \\
\text { Protein } \\
\text { Ratio } \\
\mathbf{( \% )}\end{array} \\
15.88\end{array}$} \\
\hline \multirow{5}{*}{ C. maritima } & Min & & & & & & & \\
\hline & Max. & 85.00 & 9.80 & 2472.68 & 119.55 & 66.80 & 32.00 & 18.20 \\
\hline & Mean & 79.05 & 9.17 & 1397.87 & 75.75 & 58.53 & 31.00 & 16.84 \\
\hline & SD & 5.27 & 0.56 & 971.81 & 40.80 & 9.37 & 1.00 & 1.21 \\
\hline & $\mathrm{CV}$ & 6.66 & 6.16 & 69.52 & 53.87 & 16.01 & 32.25 & 7.18 \\
\hline \multirow{5}{*}{ C. orientalis } & Min & 80.00 & 8.29 & 2264.17 & 37.54 & 5.93 & 40.00 & 19.92 \\
\hline & Max. & 205.56 & 38.70 & $26,820.15$ & 266.19 & 18.66 & 79.00 & 25.25 \\
\hline & Mean & 132.33 & 14.57 & 9958.57 & 86.02 & 10.05 & 54.73 & 22.66 \\
\hline & $\mathrm{SD}$ & 30.80 & 6.26 & 5692.41 & 62.12 & 3.30 & 7.41 & 1.56 \\
\hline & $\mathrm{CV}$ & 23.28 & 43.01 & 57.16 & 72.22 & 32.88 & 13.53 & 6.90 \\
\hline \multirow{5}{*}{ C. tataria } & Min & 80.00 & 6.00 & 2777.90 & 53.44 & 5.95 & 36.00 & 18.39 \\
\hline & Max. & 160.00 & 16.00 & $52,157.43$ & 497.18 & 41.15 & 60.00 & 26.02 \\
\hline & Mean & 104.08 & 9.70 & $12,806.34$ & 215.00 & 21.91 & 51.61 & 22.33 \\
\hline & $\mathrm{SD}$ & 21.66 & 2.78 & 9938.25 & 130.53 & 9.44 & 5.44 & 8.59 \\
\hline & $\mathrm{CV}$ & 20.81 & 28.69 & 77.60 & 60.71 & 43.09 & 10.54 & 8.59 \\
\hline
\end{tabular}


The means, coefficients of variation (CV), and ranges of the quantitative plant characteristics of the 48 Crambe accessions are presented in Table 2. Considering each Crambe species, the intraspecies Crambe accessions had very high variations in the numbers of SPP, YPP and TSW. The variation levels of the agronomic characteristics were evaluated based on species. A high level of variation was observed among the accessions of $C$. orientalis and C. tataria for the TSW and in C. maritima for the $\mathrm{H} / \mathrm{H}$. Moderate variation was observed for the $\mathrm{PH}$ in the $C$. orientalis and $C$. tataria accessions. C. maritima exhibited the lowest variations for PH and BPP (Table 2; Figures 1-3).

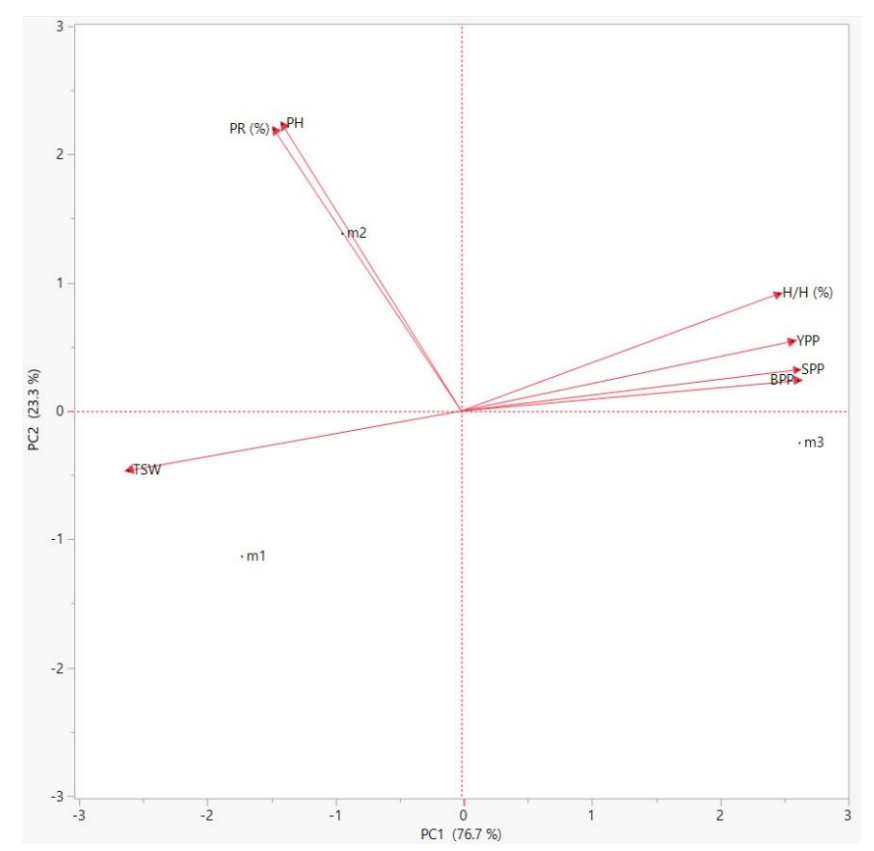

Figure 1. Biplot diagram of the protein ratio (PR) and agro-morphological properties (plant height $(\mathrm{PH})$, number of seeds per plant (SPP), yield per plant (YPP), thousand seed weight (TSW), hulless/hulled seed ratio $(\mathrm{H} / \mathrm{H})$, and number of branches per plant $(\mathrm{BPP})$ ) of $C$. maritima.

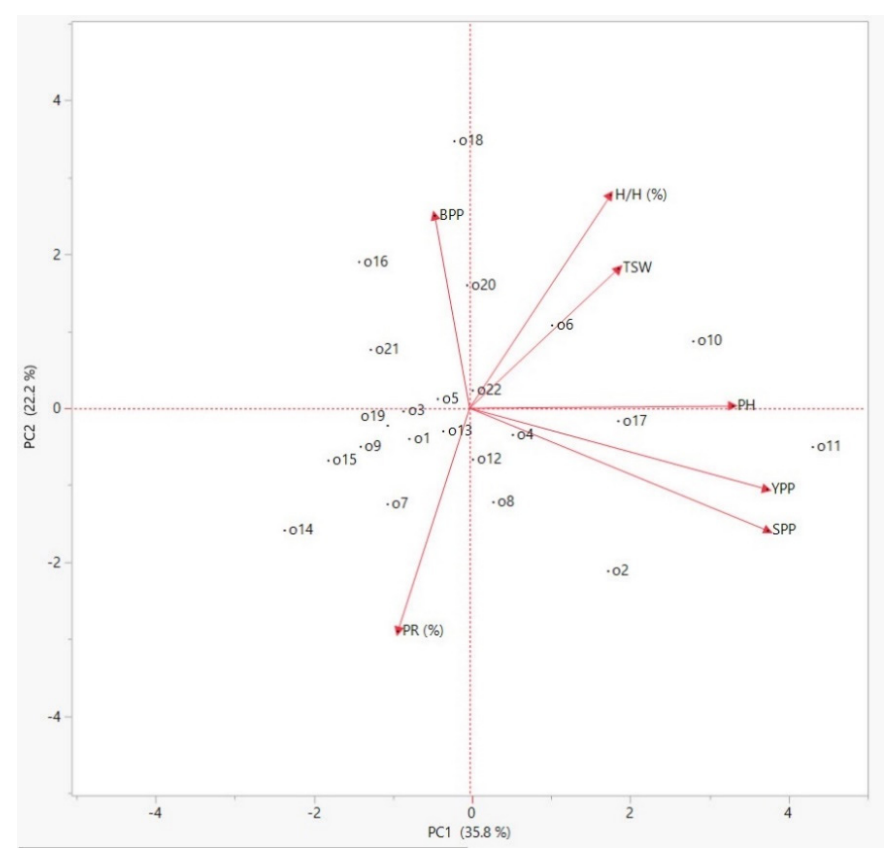

Figure 2. Biplot diagram of the protein ratio and agro-morphological properties (protein ratio (PR), plant height (PH), number of seeds per plant (SPP), yield per plant (YPP), thousand seed weight (TSW), hulless/hulled seed ratio $(\mathrm{H} / \mathrm{H})$, and number of branches per plant (BPP)) of $C$. orientalis. 


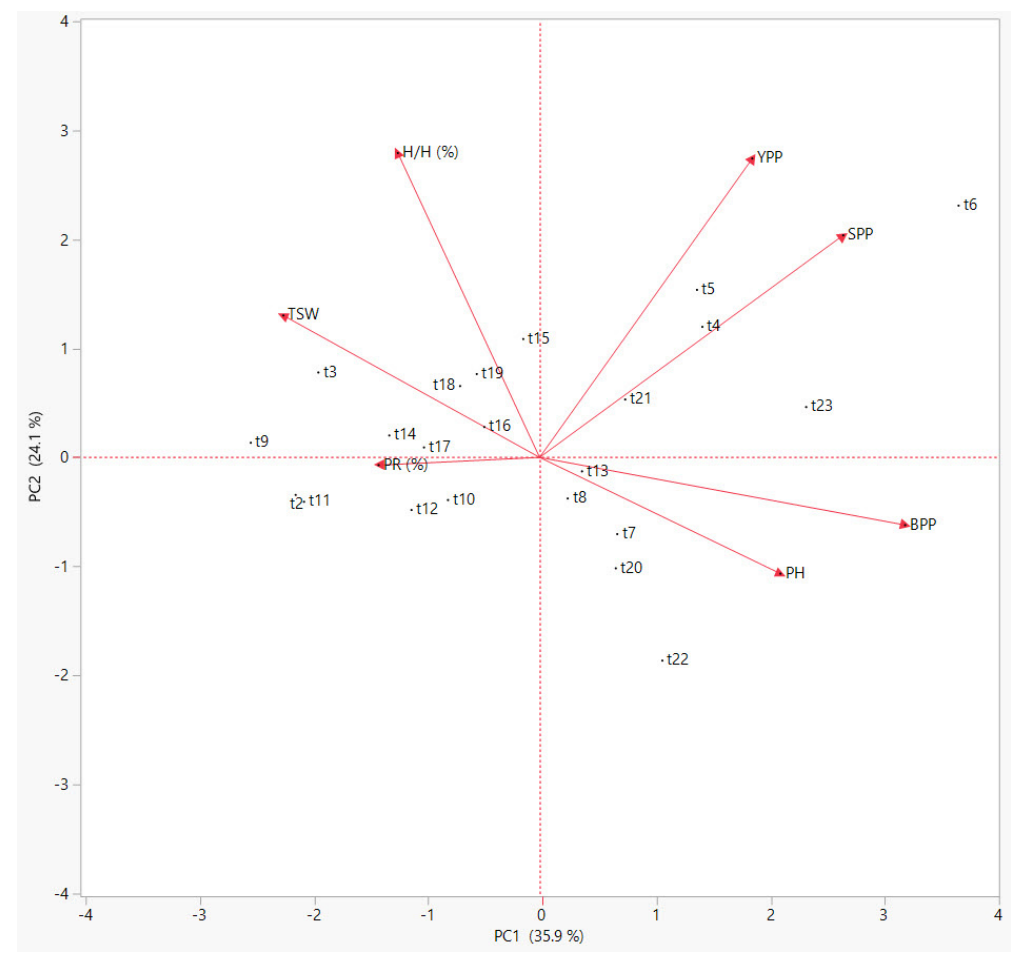

Figure 3. Biplot diagram of the protein ratio and agro-morphological properties (protein ratio (PR), plant height (PH), number of seeds per plant (SPP), yield per plant (YPP), thousand seed weight (TSW), hulless/hulled seed ratio $(\mathrm{H} / \mathrm{H})$, and number of branches per plant (BPP)) of $C$. tataria.

For the germplasm accessions, multivariate analyses were used to determine the relative contributions of the characteristics for the total variability [10]. These analyses enabled the germplasm accessions to be classified with similar characteristics. PCA was used to decrease the number of descriptors associated with the data set. Thus, the maximum amount of variability in the data could be explained. Table 3 shows the principal components (PCs) generated from the three Crambe species (C. maritima, C. orientalis, and C. tataria intraspecies accessions) and their average agro-morphological characteristics and seed PRs.

In the C. maritima data set, PC1 had the highest Eigenvalue, at 5.37, and accounted for $76.7 \%$ of the variability, while PC2 had an Eigenvalue of 1.63 and accounted for $23.3 \%$ of the variability. PCs (PC2 to PC7) with an Eigenvalue of less than 1 were not considered due to Kaiser's rule [11]. Considering the data sets of $C$. maritima, C. orientalis, $C$. tataria and the means of the species, PC1 accounted for $76.7 \%, 35.82 \%, 35.87 \%$ and $76.23 \%$ of the variability, and PC2 accounted for $23.30 \%, 22.23 \%, 24.01 \%$ and $23.77 \%$ of the variability, respectively.

Table 4 shows the correlation matrices for the studied Crambe species independently. For C. maritima, there were significant positive correlation between BPP and SPP, but significant negative correlations between TSW and both of SPP and YPP. In C. orientalis, significant positive correlations were observed between PH and both of YPP and SPP, and also between SPP and YPP. For C. tataria, there were significant positive correlations between BPP and both of $\mathrm{PH}$ and SPP, but a significant negative correlation between BBP and $\mathrm{H} / \mathrm{H}$ (Table 4).

The biplot analysis shows interrelationships among the Crambe traits visually. Figures 1-4 depict the score plots of the seed PR and agro-morphologic characteristics in three Crambe species and the means of three Crambe species, generated by comparing PC1 and PC2 axes. 
Table 3. Eigen analysis of the correlation matrix loadings of the significant PCs.

\begin{tabular}{|c|c|c|c|c|c|c|c|c|}
\hline Species & Characters & PC1 & PC2 & PC3 & PC4 & PC5 & PC6 & PC7 \\
\hline \multirow{10}{*}{ C. maritima } & $\mathrm{PH}$ & -0.530 & 0.848 & - & - & - & - & - \\
\hline & $\mathrm{BPP}$ & 0.996 & 0.090 & - & - & - & - & - \\
\hline & SPP & 0.993 & 0.122 & - & - & - & - & - \\
\hline & YPP & 0.979 & 0.206 & - & - & - & - & - \\
\hline & TSW & -0.984 & -0.176 & - & - & - & - & - \\
\hline & $\mathrm{H} / \mathrm{H}(\%)$ & 0.938 & 0.347 & - & - & - & - & - \\
\hline & PR (\%) & -0.554 & 0.832 & - & - & - & - & - \\
\hline & Eigenvalue & 5.37 & 1.63 & - & - & - & - & - \\
\hline & Variability (\%) & 76.7 & 23.3 & - & - & - & - & - \\
\hline & Cumulative (\%) & 76.74 & 100.00 & - & - & - & - & - \\
\hline \multirow{10}{*}{ C. orientalis } & $\mathrm{PH}$ & 0.485 & 0.005 & -0.265 & -0.147 & -0.310 & 0.739 & - \\
\hline & $\mathrm{BPP}$ & -0.064 & 0.462 & -0.477 & 0.735 & 0.020 & 0.048 & - \\
\hline & SPP & 0.549 & -0.294 & -0.170 & 0.021 & 0.243 & -0.143 & - \\
\hline & YPP & 0.548 & -0.195 & -0.028 & 0.272 & 0.003 & -0.459 & - \\
\hline & TSW & 0.274 & 0.335 & 0.666 & 0.226 & -0.506 & -0.052 & - \\
\hline & $\mathrm{H} / \mathrm{H}(\%)$ & 0.260 & 0.512 & 0.289 & -0.124 & 0.724 & 0.178 & - \\
\hline & PR (\%) & -0.132 & -0.536 & 0.382 & 0.545 & 0.254 & 0.431 & - \\
\hline & Eigenvalue & 2.508 & 1.557 & 0.989 & 0.796 & 0.596 & 0.485 & 0.071 \\
\hline & Variability (\%) & 35.825 & 22.235 & 14.123 & 11.371 & 8.507 & 6.927 & 1.012 \\
\hline & Cumulative (\%) & 35.825 & 58.06 & 72.183 & 83.553 & 92.06 & 98.988 & 100 \\
\hline \multirow{10}{*}{ C. tataria } & $\mathrm{PH}$ & 0.363 & -0.224 & 0.475 & -0.100 & 0.717 & -0.209 & 0.160 \\
\hline & $\mathrm{BPP}$ & 0.551 & -0.130 & 0.055 & 0.345 & -0.102 & 0.739 & 0.042 \\
\hline & SPP & 0.457 & 0.428 & -0.057 & -0.289 & -0.299 & -0.203 & 0.625 \\
\hline & YPP & 0.320 & 0.576 & 0.292 & 0.196 & -0.075 & -0.226 & -0.621 \\
\hline & TSW & -0.386 & 0.273 & 0.363 & 0.669 & 0.027 & -0.025 & 0.442 \\
\hline & $\mathrm{H} / \mathrm{H}(\%)$ & -0.214 & 0.586 & -0.203 & -0.267 & 0.523 & 0.474 & 0.017 \\
\hline & PR (\%) & -0.243 & -0.015 & 0.714 & -0.480 & -0.327 & 0.305 & -0.026 \\
\hline & Eigenvalue & 2.511 & 1.684 & 1.185 & 0.720 & 0.582 & 0.210 & 0.107 \\
\hline & Variability (\%) & 35.868 & 24.059 & 16.928 & 10.290 & 8.320 & 3.002 & 1.531 \\
\hline & Cumulative (\%) & 35.868 & 59.927 & 76.856 & 87.146 & 95.466 & 98.469 & 100.000 \\
\hline \multirow{10}{*}{$\begin{array}{c}\text { Means of } 3 \\
\text { species }\end{array}$} & $\mathrm{PH}$ & 0.399 & -0.300 & - & - & - & - & - \\
\hline & $\mathrm{BPP}$ & 0.302 & -0.556 & - & - & - & - & - \\
\hline & SPP & 0.400 & 0.297 & - & - & - & - & - \\
\hline & YPP & 0.180 & 0.705 & - & - & - & - & - \\
\hline & TSW & -0.432 & 0.058 & - & - & - & - & - \\
\hline & $\mathrm{H} / \mathrm{H}(\%)$ & 0.431 & 0.069 & - & - & - & - & - \\
\hline & PR (\%) & 0.430 & 0.087 & - & - & - & - & - \\
\hline & Eigenvalue & 5.336 & 1.664 & - & - & - & - & - \\
\hline & Variability (\%) & 76.229 & 23.771 & - & - & - & - & - \\
\hline & Cumulative (\%) & 76.229 & 100 & - & - & - & - & - \\
\hline
\end{tabular}

Protein ratio (PR), plant height (PH), number of seeds per plant (SPP), yield per plant (YPP), thousand seed weight (TSW), hulless/hulled seed ratio $(\mathrm{H} / \mathrm{H})$, and number of branches per plant (BPP).

In the biplot diagram of C. maritima (Figure 1), H/H, YPP, SPP and BPP showed a positive correlation. The genotype $\mathrm{m} 2$ had a higher $\mathrm{PH}$ and $\mathrm{PR}$ with respect to the other genotypes. While the $\mathrm{m} 1$ genotype stood out in terms of TSW, the $\mathrm{m} 3$ genotype had a higher BPP, SPP, YPP and $\mathrm{H} / \mathrm{H}$ with respect to the other genotypes.

Figure 2 shows a biplot diagram of the $C$. orientalis accessions. The positive axis of PC1 contained H/H, TSW, PH, YPP and SPP, and was comprised of o6, o10, o17, o11, o2, $\mathrm{o} 8$ and $\mathrm{o} 4$ accessions. The negative axis of PC1 and PC2 contained PR, and was comprised of o14, o7, o15, o9, o1, o19 and o13 accessions.

Figure 3 shows the biplot diagram of Crambe tataria accessions. The positive axis of PC1 contained YPP, SPP, BPP and PH, and was comprised of $\mathrm{t} 6, \mathrm{t} 5, \mathrm{t} 4, \mathrm{t} 21, \mathrm{t} 23, \mathrm{t} 13, \mathrm{t} 8, \mathrm{t} 7$, $\mathrm{t} 20$ and $\mathrm{t} 22$ accessions. The negative axis of PC1 and PC2 contained H/H, TSW and PR, and was comprised of $\mathrm{t} 15, \mathrm{t} 19, \mathrm{t} 18, \mathrm{t} 16, \mathrm{t} 3, \mathrm{t} 9, \mathrm{t} 14, \mathrm{t} 17, \mathrm{t} 2, \mathrm{t} 11, \mathrm{t} 12$ and $\mathrm{t} 10$ accessions. 
Table 4. Pearson's correlation coefficient analysis for the different plant characteristics of Crambe species (protein ratio (PR), plant height (PH), number of seeds per plant (SPP), yield per plant (YPP), thousand seed weight (TSW), hulless/hulled seed ratio $(\mathrm{H} / \mathrm{H})$, and number of branches per plant (BPP)).

\begin{tabular}{|c|c|c|c|c|c|c|c|}
\hline & $\mathrm{PH}$ & BPP & SPP & YPP & TSW & H/H (\%) & $\operatorname{PR}(\%)$ \\
\hline \multicolumn{8}{|c|}{ Crambe maritima } \\
\hline $\mathrm{PH}$ & 1.000 & & & & & & \\
\hline BPP & -0.452 & 1.000 & & & & & \\
\hline SPP & -0.423 & $0.999 *$ & 1.000 & & & & \\
\hline YPP & -0.344 & 0.993 & 0.996 & 1.000 & & & \\
\hline TSW & 0.372 & -0.999 & $-0.998 *$ & $-0.996 *$ & 1.000 & & \\
\hline H/H (\%) & -0.203 & 0.965 & 0.973 & 0.989 & -0.984 & 1.000 & \\
\hline PR (\%) & $0.999 *$ & -0.477 & -0.449 & -0.371 & 0.399 & -0.231 & 1.000 \\
\hline \multicolumn{8}{|c|}{ Crambe orientalis } \\
\hline $\mathrm{PH}$ & 1.000 & & & & & & \\
\hline $\mathrm{BPP}$ & -0.023 & 1.000 & & & & & \\
\hline SPP & $0.602 * *$ & -0.203 & 1.000 & & & & \\
\hline YPP & $0.482 *$ & -0.071 & $0.854^{* *}$ & 1.000 & & & \\
\hline TSW & 0.206 & 0.010 & 0.058 & 0.305 & 1.000 & & \\
\hline $\mathrm{H} / \mathrm{H}(\%)$ & 0.190 & 0.130 & 0.158 & 0.134 & 0.388 & 1.000 & \\
\hline PR (\%) & -0.220 & -0.213 & 0.013 & -0.005 & -0.109 & -0.311 & 1.000 \\
\hline \multicolumn{8}{|l|}{ Crambe tataria } \\
\hline $\mathrm{PH}$ & 1.000 & & & & & & \\
\hline $\mathrm{BPP}$ & $0.483 *$ & 1.000 & & & & & \\
\hline SPP & 0.139 & $0.452 *$ & 1.000 & & & & \\
\hline YPP & 0.193 & 0.351 & 0.703 & 1.000 & & & \\
\hline TSW & -0.278 & -0.407 & -0.384 & 0.145 & 1.000 & & \\
\hline $\mathrm{H} / \mathrm{H}(\%)$ & -0.313 & $-0.461^{*}$ & 0.136 & 0.242 & 0.267 & 1.000 & \\
\hline PR (\%) & 0.070 & -0.338 & -0.196 & -0.028 & 0.296 & -0.033 & 1.000 \\
\hline
\end{tabular}

${ }^{*}, * *$ Indicate significance at the $5 \%$ and $1 \%$ levels, respectively.

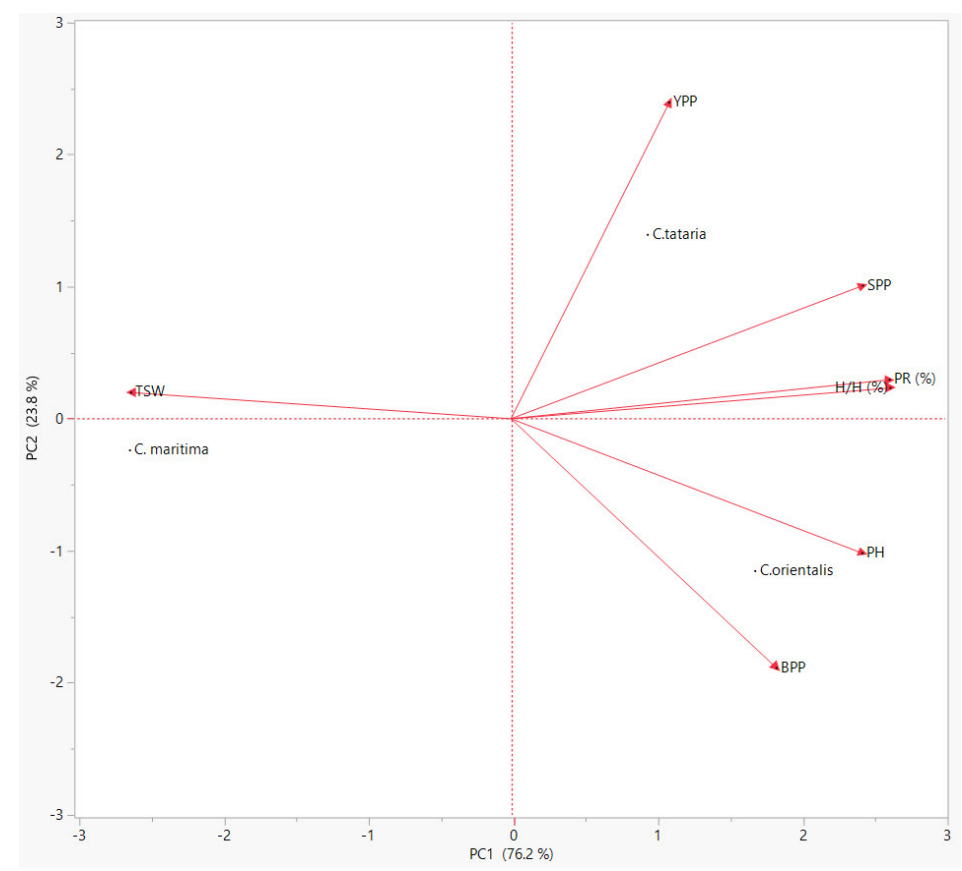

Figure 4. Biplot diagram of the protein ratio and agro-morphological properties (protein ratio (PR), plant height (PH), number of seeds per plant (SPP), yield per plant (YPP), thousand seed weight (TSW), hulless/hulled seed ratio $(\mathrm{H} / \mathrm{H})$, and number of branches per plant (BPP)) among the species (Crambe maritima, Crambe orientalis and Crambe tataria). 
Figure 4 shows the bioplot diagram of Crambe species (mean of the accessions of intraspecies). C. maritima had the highest TSW among the species. While C. tataria had higher YPP and SPP, C. orientalis had higher PH and BPP than the other species.

\section{Discussion}

The minimum, maximum, and mean values of wild Crambe accessions examined in this study are shown in Table 2. Davis [12], Keskiner [13], Comlekcioglu et al. [14], Gökçe [15] and Köybaş1 [16] reported the maximum and minimum PHs in C. orientalis as 40 and $120 \mathrm{~cm}, 35$ and $110 \mathrm{~cm}, 71$ and $120 \mathrm{~cm}$, and 95.21 and $31.6 \mathrm{~cm}$, respectively. In this research, the minimum and maximum PHs of C. orientalis were 80 and $205 \mathrm{~cm}$, and the average was $132.33 \mathrm{~cm}$, which was higher than the above-mentioned values. For $C$. tataria, a higher PH $(80-160 \mathrm{~cm})$ was determined than that reported by Comlekcioglu et al. [14] (73-116 cm), Davis [12] (90-100 cm), Gökçe [15] (89.31) and Köybaşı [16] (37.5 cm). The BPP values obtained in the current research for $C$. tataria (6-16 branches) and C. orientalis (8.29-38.7 branches) were higher than those reported by Comlekcioglu et al. [14] (2-15 and 1-10 branches, respectively), Gökçe [15] (2.94 and 1.56 branches, respectively) and Köybaş1 [16] (15.1 and 12 branches, respectively). For C. orientalis and C. tataria, the TSW values were determined to be between 5.93 and $18.66 \mathrm{~g}$ and 5.95 and $41.15 \mathrm{~g}$, respectively. This finding is similar to those reported by Comlekcioglu et al. [14] at 9-18 g and 10-29 g, Gökçe [15] at $5.95 \mathrm{~g}$ and $7.69 \mathrm{~g}$, and Köybaş1 [16] at $15.04 \mathrm{gr}$ for C. orientalis. Köybaş1 [16] reported $72.25 \mathrm{~g}$ for C. tataria in the same study. For C. orientalis and C. tataria, the YPP (g) was between 37.54 and $266.19 \mathrm{~g}$ and 53.44 and $497.18 \mathrm{~g}$, respectively. This finding was higher than that reported by Gökçe [15] (33.78 g and $33.00 \mathrm{~g}$, respectively) and Köybaş1 [16] (20.61 g and $31.07 \mathrm{~g}$, respectively). For C. orientalis and C. tataria, the seeds per plant was between 2264.17 and $26,820.15$ seeds and 2777.90 and 52,157.43 seeds, respectively. This finding is higher than that reported by Gökçe [15], which was 2486.05 seeds and 1823.16 seeds, respectively, and that reported by Köybaş1 [16], which was 1885.8 seeds and 379.0 seeds, respectively. The variation was high between the mentioned characteristics of C. maritima, C. orientalis and C. tataria accessions. Davis [12], Keskiner [13], Comlekcioglu et al. [14], Gökçe [15] and Köybaşı [16] used fewer population genotypes in their wild Crambe studies, and their reported values are between the minimum and maximum values of this study, but may differ from the average values. Large variations can be seen within and between populations because of their not being stabilized genotypes. In addition, the difference in the values is the result of carrying out each study in different climatic conditions.

There are few records about the agro-morphological features of wild species. However, many studies exist on annually cultivated Crambe species. The morphological features of these annual species are quite different from the morphological features of perennial wild Crambe species. C. abbysinica species were reported with an $\mathrm{H} / \mathrm{H}$ of $24-28.8 \%$ [17,18]. However, the $\mathrm{H} / \mathrm{H}$ was determined as $30-79 \%$ in the wild Crambe species in the current study. Mastebroek et al. [19] reported the means for C. abyssinica Hochst. as 116 plants $/ \mathrm{m}^{2}$, and the average YPP as $2.5 \mathrm{~g}$. Arslan et al. [20] reported TSW values between 2.6 and $8.5 \mathrm{~g}$ and YPP values of $0.8-5.1 \mathrm{~g} / \mathrm{plant}$ for $82 \mathrm{C}$. abyssinica genotypes. Nevertheless, in the wild Crambe species in this study, there were approximately 4.5 plants $/ \mathrm{m}^{2}$, and the average YPP was $125.5 \mathrm{~g}$. The PR, determined as $22.7 \%$ for $C$. orientalis and $22.3 \%$ for C. tataria in this study, had values similar to those reported by Sokolski et al. [21] as 20.8-23.8\% in the culture form of Crambe (Crambe abyssinica Hochst. ex RE Fries). Annual Crambe species are morphologically quite different from wild perennial Crambe species. Therefore, there were great differences between all the features. Although the YPP is high in C. tataria and C. orientalis, it has been observed that these species are not suitable for conventional agriculture at the moment due to shell thickness, nonhomogeneous plant emergence and shooting. 


\section{Conclusions}

Crambe species have good potential for use in industrial oil and animal feed (as a source of protein). C. tataria and C. orientalis are not suitable for conventional agriculture. The conventional cultivation of Crambe is only possible by eliminating negative features via breeding and agronomic studies.

Funding: This research was funded by the General Directorate of Agricultural Research and Policy (Republic of Turkey Ministry of Agriculture and Forestry).

Institutional Review Board Statement: Not applicable.

Informed Consent Statement: Not applicable.

Data Availability Statement: The data are available on request.

Acknowledgments: I would like to express my cordial thanks to Yusuf Arslan, Burcu Tarikahya Hacıoglu and Asiye Seis Subaşı for their technical contribution to the manuscript.

Conflicts of Interest: The authors declare no conflict of interest.

\section{References}

1. Warwick, S.I.; Francis, A.; Gugel, R.K. Guide to Wild Germplasm of Brassica and Allied Crops (Tribe Brassiceae, Brassicaceae), 3rd ed.; Agriculture and Agri-Food Canada: Ottawa, ON, Canada, 2009; Crops 1-6.

2. Mutlu, B. Türkiye Bitkileri Listesi (Damarlı Bitkiler). In Crambe; Güner, A., Aslan, S., Ekim, T., Vural, M., Babac, M.T., Eds.; Nezahat Gökyiğit Botanik Bahçesi ve Flora Araştırmaları Derneği Yayını: Istanbul, Turkey, 2012.

3. Bülbül, A.S.; Tarıkahya-Hacioğlu, B.; Arslan, Y.; Subaşı, I. Pollen and seed morphology of Crambe species of Turkey. J. Anim. Plant Sci. 2017, 27, 1331-1339.

4. Tarikahya-Hacioğlu, B. Molecular diversity of the wild Crambe (Brassicaceae) taxa in Turkey detected by inter-simple sequence repeats (ISSRs). Ind. Crop. Prod. 2016, 80, 214-219. [CrossRef]

5. Dolya, V.S.; Shkurupii, E.N.; Podzolkova, T.V.; Kaminskii, N.A. The seed oils of some species of the family Cruciferae. Chem. Nat. Compd. 1973, 9, 12-14. [CrossRef]

6. Gecer, M.K.; Kan, T.; Gundogdu, M.; Ercisli, S.; Ilhan, G.; Sagbas, H.I. Physicochemical characteristics of wild and cultivated apricots (Prunus armeniaca L.) from Aras valley in Turkey. Genet. Resour. Crop. Evol. 2020, 67, 935-945. [CrossRef]

7. Smith, J.S.C.; Smith, O.S. The description and assessment of distances between inbred lines of maize: The utility of morphological, biochemical, and genetic descriptors and a scheme for the testing of distinctiveness between inbred lines. Maydica 1989, 34, 151-161.

8. Berdahl, J.D.; Mayland, H.F.; Asay, K.H.; Jefferson, P.G. Variation in agronomic and morphological traits among Russian wild rye accessions. Crop Sci. 1999, 39, 1890-1895. [CrossRef]

9. Poonam, T.; Sharma, K.; Mishra, S.K. Agro-morphological characterization of diverse germplasm of lentil (Lens culinaris Medik.). New Bot. 2006, 33, 225-235.

10. Baloch, F.S.; Karaköy, T.; Demirbaş, A.; Toklu, F.; Özkan, H.; Hatipoğlu, R. Variation of some seed mineral contents in open pollinated faba bean (Vicia faba L.) landraces from Turkey. Turk. J. Agric. For. 2014, 38, 591-602. [CrossRef]

11. Kaiser, H.F. The application of electronic computers to factor analysis. Educ. Psychol. Meas. 1960, 20, 141-151. [CrossRef]

12. Davis, P.H. Flora of Turkey and East Eagen Islands; Edinburgh at the University Press: Edinburgh, UK, 1982; Volume 1, pp. $272-273$.

13. Keskiner, S. Crambe orientalis, L. üzerinde morfolojik, anatomik, karyolojik ve doku kültürü (embriyo kültürü) çalışmaları. Master's Thesis, Department of Biology, Institute of Natural and Applied Sciences, University of Anadolu, Eskişehir, Turkey, 1992.

14. Comlekcioglu, N.; Karaman, S.; Ilcim, A. Oil composition and some morphological characters of Crambe orientalis var. orientalis and Crambe tataria var. tataria from Turkey. Nat. Prod. Res. 2008, 22, 525-532. [CrossRef]

15. Gökçe, C.A. Niğde İlinde Doğal Yayılış Gösteren rambe Türlerinin Teşhisi ve Kalite Özelliklerinin Belirlenmesi, Fen Bil. Ens. Master's Thesis, Çukurova University, Adana, Turkey, 2015.

16. Köybaşı, Ö. Çukurova Koşullarında Bazı Crambe Türlerinin Verim ve Yağ Oranlarının Saptanması, Fen Bil. Ens. Master's Thesis, Çukurova University, Adana, Turkey, 2008.

17. Cornelius, J.A.; Simmons, E.A. Crambe abyssinica. A new commercial oil seed. Trop. Sci. 1966, 11, 17-22.

18. Lazzeri, L.; Leoni, O.; Conte, L.S.; Palmieri, S. Some technological characteristics and potential uses of Crambe abyssinica products. Ind. Crops Prod. 1994, 3, 103-112. [CrossRef]

19. Mastebroek, H.D.; Wallenburg, S.C.; Van Soest, L.J.M. Variation for agronomic characteristics in Crambe (Crambe abyssinica Hochst. ex Fries). Ind. Crop. Prod. 1994, 2, 129-136. [CrossRef]

20. Arslan, Y.; Subaşi, I.; Keyvanoğlu, H. Determination of Some Plants Characteristics of Crambe (Crambe hispanica subsp. abyssinica) Genotypes. Tarla Bitk. Merk. Araştırma Enstitüsü Derg. 2015, 24, 16-23.

21. Sokólski, M.; Załuski, D.; Jankowski, K. Crambe: Seed Yield and Quality in Response to Nitrogen and Sulfur-A Case Study in Northeastern Poland. Agronomy 2020, 10, 1436. [CrossRef] 